\title{
Antibacterial Effects of Methanol Extracts of Some Plant Species Belonging to Lamiaceae Family
}

\author{
Ceren YAVUZ ${ }^{1}$, Duygu Dereli KILIÇ ${ }^{2}$, Arif AYAR ${ }^{1}$, Tuba YILDIRIM ${ }^{1 *}$ \\ ${ }^{1}$ Department of Biology, Faculty of Arts and Sciences, Amasya University, Amasya, Turkey \\ ${ }^{2}$ Sabuncuoğlu Şerefeddin Health Services Vocational School, Amasya University, Amasya, Turkey
}

Received: 03 May 2017 - Revised: 18 September 2017 - Accepted: 03 November 2017

\begin{abstract}
Species belonging to Lamiaceae family are used as an antibacterial agent among medical plants. The aim of the present study was to determinate the antibacterial effects of the methanolic extracts of some plant species belonging Lamiaceae family which distributed to different ecological conditions in Amasya. The antibacterial effects of Stachys annua, Scutellaria salviifolia and Nepata nuda plant extracts were determined by disc diffusion and micro dilution methods. The antibacterial effects of plant extracts were tested against standard strains of Staphylococcus aureus ATCC 25923, Escherichia coli ATCC 35218, Klebsiella pneumoniae ATCC 70600, Pseudomonas aeruginosa ATCC 27853 and Salmonella enteritidis ATCC 13076. We observed that plant extracts had antibacterial effect when they compared with control group antibiotics. According to the results of disc diffusion method, the highest antibacterial effect was identified in Scutellaria salviifolia, Stachys annua and Nepata nuda, respectively. The microdilution method was studied concentration range from 6.25 - to $50 \mathrm{mg} / \mathrm{ml}$. MICs of the most effective Scutellaria salviifolia plant extract were $12.5 \mathrm{mg} / \mathrm{ml}$ for $S$. aureus, S. enteritidis and $E$. coli; $25 \mathrm{mg} / \mathrm{ml}$ for K. pneumoniae and P. aeruginosa. The MICs of Stachys annua extract were $12.5 \mathrm{mg} / \mathrm{ml}$ for $P$. aeruginosa, S. enteritidis and E. coli; $25 \mathrm{mg} / \mathrm{ml}$ for $S$. aureus and $50 \mathrm{mg} / \mathrm{ml}$ for K. pneumoniae. MICs of Nepata nuda were $12.5 \mathrm{mg} / \mathrm{ml} \mathrm{K}$. pneumonia; $25 \mathrm{mg} / \mathrm{ml}$ for $S$. aureus; $50 \mathrm{mg} / \mathrm{ml}$ for P. aeruginosa, S. enteritidis and $E$. coli. This study showed that Scutellaria salviifolia, Stachys annua and Nepata nuda species have in vitro antibacterial activities.
\end{abstract}

Keywords: Lamiaceae, Disc diffusion, Micro dilution

\section{INTRODUCTION}

The treatment of infectious diseases with antimicrobial agents shows several problems in modern-day medicine, causing bacterial resistance to several antibiotics [1]. Therefore, biologically active extracts and compounds from plants have commonly been studied to discover new sources [2-6]. Medicinal plants and herbs have been used for many years in treatments of various animal and human diseases. Antimicrobial properties of medicinal plants are being increasingly reported from different parts of the world [8-11]. The antimicrobial compounds from plants may inhibit bacterial growth by different mechanisms than those presently used [13-15].

Lamiaceae (Labiatae) also called as the mint family, is a family of flowering plants. A very important medicinal plant family is the Lamiaceae family stands for about more than 3000

*Corresponding Author E-mail: yildirimt55@gmail.com; tuba.yildirim@amasya.edu.tr 
species of plants spread in the warm and temperate region all over the world. In aromatherapy, the oil is used for its soothing effects with sedative, diuretic, tonic, antiseptic properties [16].

Lamiaceae species are important among plants, which are used in research of antimicrobial activity. Turkey is regarded as an important gene center for Lamiaceae family [10, 17]. Stachys annua, Scutellaria salviifolia and Nepata nuda species belonging to Lamiaceae family which is one of the largest families of flowering plants are widely used in folk medicine of many nations $[18,19]$.

The rich tradition of usage of medicinal plants for the treatment of various diseases in many parts of Turkey. Therefore, in this study our aim was to screen selected Turkish medicinal plants for their antimicrobial activity in vitro. Extracts were obtained from the flowers, leaves and stems of three different plant species using methanol as solvents and determinated the antibacterial effects of the methanolic extracts of some plant species belonging Lamiaceae family which distributed to different ecological conditions in Amasya.

\section{MATERIAL and METHODS}

\subsection{Plant material}

The plant species were selected based on their traditional uses reported in available literature [20]. Stachys annua, Scutellaria salviifolia and Nepata nuda of Lamiaceae family were collected (between April and May 2015) from the Amasya region of Turkey. The parts used for the study were leaves, stems and flowers.

\subsection{Preparation of extracts}

The plant parts were separated, air-dried at room temperature, and powdered finely using a grinder. Powdered plant material was extracted from each specimen using a Soxholet extractor using methanol solvent. The solvent was removed in a rotary vacuum evaporator [21]. The evaporated extract was weighed then dissolved in dimethyl sulfoxide (DMSO) (Sigma, Steinheim, Germany) to a final concentration of $50 \mathrm{mg} / \mathrm{ml}$. All extracts were sterilized by filtering them through a $0.45 \mu \mathrm{m}$ nylon membrane filter and stored at $+4^{\circ} \mathrm{C}$ until use.

\subsection{Test organisms and growth conditions}

A clinical isolate was obtained from the Department of Biology, Faculty of Arts and Sciences, Amasya University. Cultures were prepared from stock cultures employing the streaking technique on Mueller-Hinton agar (MHA) (Oxoid, Hampshire, England) plates for bacteria. After overnight incubation, a single colony was used to inoculate the sterile broths: Muller Hinton broth (MHB) (Oxoid, Hampshire, England) for bacteria. The inoculated broths were then incubated overnight. The microbial cultures were diluted in MHB and adjusted to a turbidity level of $0.5 \mathrm{McFarland}$ standard tube (about $10^{8}$ cell $/ \mathrm{ml}$ ).

\subsection{Screening for antimicrobial activities}

\subsubsection{Disc Diffusion Method}

Agar disc diffusion method was employed for the determination of antimicrobial activities of the extracts against reference bacterial strains $S$. aureus ATCC 25923, E. coli ATCC 35218, K. pneumoniae ATCC 70600, P. aeruginosa ATCC 27853 and S. enteritidis ATCC 13076 [22]. Suspensions of the microorganism $(20 \mu 1)$ was added and spread evenly on MHA preset in $90-\mathrm{mm}$ petri dishes. A suspension of the test microorganism $\left(0.1 \mathrm{ml}\right.$ from $10^{8}$ cells per $\mathrm{ml}$ ) was spread on the solid media plates. Filter paper discs (sterilized discs) $(6 \mathrm{~mm}$ in diameter) prepared with Whatman filter paper No.1 (Oxoid, UK). Standard discs of gentamicin $(10 \mu \mathrm{g} / \mathrm{disc})$ and ceftriaxone $(50 \mu \mathrm{g} / \mathrm{disc})$ were used as positive controls for bacteria whereas DMSO discs were used as negative control. Petri dishes were preincubated at $+4^{\circ} \mathrm{C}$ for $2 \mathrm{~h}$ to 
allow uniform diffusion of extracts into the agar. After preincubation, the plates with bacteria were incubated at $37^{\circ} \mathrm{C}$ for $24 \mathrm{~h}$. The antimicrobial activities were evaluated by measuring the inhibition zone diameter observed. All of the tests were performed three times, the diameters of the inhibition zones were measured in millimeters, and the data was recorded as the mean diameter (mm).

\subsubsection{Determination of minimum inhibitory concentration (MIC)}

Broth microdilution method was used to determine the minimum inhibitory concentration (MIC) according to the National Committee for Clinical Laboratory Standards [22]. The MIC value was determined for the selected active extracts. In this study, S. aureus ATCC 25923, E. coli ATCC 35218, K. pneumoniae ATCC 70600, P. aeruginosa ATCC 27853 and S. enteritidis ATCC 13076 standard strains were tested. The MIC value was determined by the broth microdilution method using 96- well microtiter plates. Two-fold serial dilutions of extracts were prepared by dilution with DMSO (25\%) to achieve a decreasing concentration range from 1 to $50 \mathrm{mg} / \mathrm{ml}$. The bacterial inoculates were prepared using overnight cultures and suspensions were adjusted to $0.5 \mathrm{McF}$ arland standard turbidity using turbidimeter. Each well was inoculated with $100 \mu \mathrm{l}$ of the bacterial suspension at a density of $10^{6}$ cell $/ \mathrm{ml}$. Additionally, inhibitory activity of the DMSO against test strains was checked. The inoculated 96-well microtiter plates were incubated for $24 \mathrm{~h}$ at $37^{\circ} \mathrm{C}$, for bacterial cultures. The lowest concentration of the extract that prevented visible growth was evaluated as the MIC. All samples were examined in two separate experiments.

\section{RESULTS and DISCUSSIONS}

Many microorganisms causing damage to human health exhibit drug resistance due to inadequate use of antibiotics. Thus, there is a need for the discovery of new substances from natural sources including plants. Antimicrobial activities of plants belonging to Lamiaceae families were evaluated in vitro against bacterial species. All plants tested in this study showed antimicrobial activity against some of the test microorganisms, with inhibition zones that ranged from 11 to $17 \mathrm{~mm}$ (Table 1). Results showed that all of the plants tested possessed antimicrobial activity against at least one of the test microorganism.

According to the results of disc diffusion method, the highest antibacterial effect was identified in Scutellaria salviifolia, Stachys annua and Nepata nuda, respectively. The sensitivity of Gram negative bacteria against to extract of Scutellaria salviifolia, Stachys annua and Nepata nuda was in the order of E. coli > P. aeruginosa > S.enteritidis >.K. pneumoniae. Plant extracts generally inhibited Gram negative and Gram positive bacteria with inhibition zone diameters that ranged from 11 to $17 \mathrm{~mm}$. DMSO was used as a negative control with no antimicrobial effect on the microorganisms tested. On the other hand gentamisin and ceftriaxone as positive control antibiotics had antimicrobial effect on the microorganisms tested. The most active extracts were obtained when methanol as a solvent (Table 1).

The minimum inhibitory concentration of selected active extracts ranged from 6.25 - to $50 \mathrm{mg} / \mathrm{ml}$. The minimum inhibition concentrations (MIC) of the most effective Scutellaria salviifolia plant extract were $12.5 \mathrm{mg} / \mathrm{ml}$ for $S$. aureus, S. enteritidis and E. coli; $25 \mathrm{mg} / \mathrm{ml}$ for $K$. pneumoniae and P. eruginosa. The MICs of Stachys annua plant extract were $12.5 \mathrm{mg} / \mathrm{ml}$ for $P$. aeruginosa, S. enteritidis and E. coli; $25 \mathrm{mg} / \mathrm{ml}$ for $S$. aureus; $50 \mathrm{mg} / \mathrm{ml}$ for $K$. pneumoniae. MICs of Nepata nuda plant extract were $12.5 \mathrm{mg} / \mathrm{ml}$ K. pneumonia; $25 \mathrm{mg} / \mathrm{ml}$ for $S$. aureus; $50 \mathrm{mg} / \mathrm{ml}$ for $P$. aeruginosa, S. enteritidis and E. coli (Table 2). 
Table 1. Results of the screening of three plant extracts belonging to Lamiaceae family by means of the disc diffusion method.

\begin{tabular}{|c|c|c|c|c|c|}
\hline \multirow{2}{*}{ Plant extracts } & \multicolumn{4}{|c|}{$\begin{array}{l}* \text { Zone of Inhibitions }(\mathrm{mm}) \\
* * \text { Microorganisms }\end{array}$} & \multirow[b]{2}{*}{$* * \mathrm{~S}$. ent. } \\
\hline & ** St. a. & $* *$ E. c. & $* * \mathrm{~K} . \mathrm{p}$ & $* *$ P. a. & \\
\hline Scutellaria salviifolia & 16 & 12 & 9 & 11 & 14 \\
\hline Stachys annua & 7 & 17 & - & 14 & 9 \\
\hline Nepata nuda & 11 & - & 13 & - & - \\
\hline ***Gentamisin & 22 & 24 & 17 & 25 & 25 \\
\hline ***Ceftriaxone & 9 & 35 & 25 & 27 & 18 \\
\hline ****DMSO & - & - & - & - & - \\
\hline \multicolumn{6}{|c|}{ 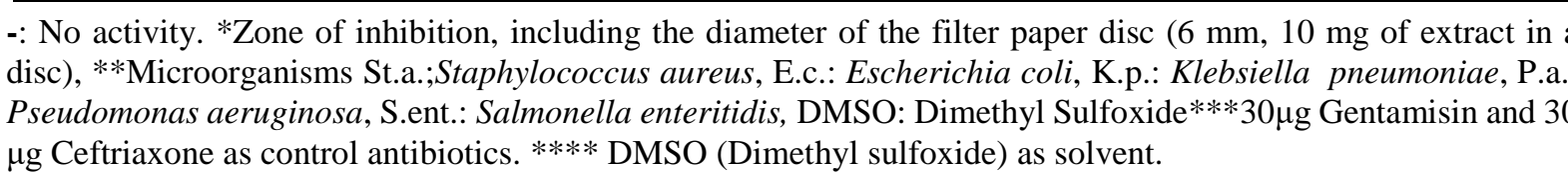 } \\
\hline \multicolumn{6}{|c|}{$\begin{array}{l}\text { Tablo 2. Results of the screening of three plant extracts belonging to Lamiaceae family by means of th } \\
\text { minimum inhibition concentrations (MIC) method }\end{array}$} \\
\hline \multirow[t]{2}{*}{ Samples } & \multicolumn{4}{|c|}{$\begin{array}{l}\text { * Microorganisms } \\
* * \text { MIC }(\mathrm{mg} / \mathrm{ml})\end{array}$} & \\
\hline & St. a. & E. c. & K. p. & P. a. & S. ent. \\
\hline Scutellaria salviifolia & 12.5 & 12.5 & 25 & 25 & 12.5 \\
\hline Stachys annua & 25 & 12.5 & 50 & 12.5 & 12.5 \\
\hline Nepata nuda & 25 & 50 & 12.5 & $\geq 50$ & $\geq 50$ \\
\hline
\end{tabular}

* Microorganisms: St.a; Staphylococcus aureus, E.c.: Escherichia coli, K.p.: Klebsiella pneumoniae, P.a.: Pseudomonas aeruginosa, S.ent.: Salmonella enteritidis.

\section{CONCLUSION}

Difference in antibacterial activities may be related to the concentration and nature of contents, the functional groups, the structural configuration of the components and their possible synergistic interaction. The present work has shown that these plant species are potentially good sources of antimicrobial agents. However, the extracts from Scutellaria salviifolia possessed remarkable antimicrobial action against some microorganisms tested in this study. Therefore, further phytochemical studies are required to determine the types of compounds responsible for the antimicrobial effects of these plants.

\section{Conflict of Interests}

Authors declare that there is no conflict of interests.

\section{REFERENCES}

[1] Kumarasamy, Y., Cox, P. J., Jaspars, M., Nahar, L., \& Sarker, S. D. (2002). Screening seeds of Scottish plants for antibacterial activity. Journal of Ethnopharmacology, 83(1), 73-77.

[2] Kianbakht, S., \& Jahaniani, F. (2003). Evaluation of antibacterial activity of Tribulus terrestris L. growing in Iran. Iranian Journal of Pharmacology \& Therapeutics (IJPT), 2(1), 22-24.

[3] Chung, P. Y., Chung, L. Y., Ngeow, Y. F., Goh, S. H., \& Imiyabir, Z. (2004). Antimicrobial activities of Malaysian plant species. Pharmaceutical biology, 42(4-5), 292-300. 
[4] Unal, E. L., Mavi, A., Kara, A. A., Cakir, A., Şengül, M., \& Yildirim, A. (2008). Antimicrobial and antioxidant activities of some plants used as remedies in Turkish traditional medicine. Pharmaceutical Biology, 46(3), 207-224.

[5] Kunduhoglu, B., Pilatin, S., \& Caliskan, F. (2011). Antimicrobial screening of some medicinal plants collected from Eskisehir, Turkey. Fresenius Environmental Bulletin, 20(4), 945-952.

[6] Essawi, T., \& Srour, M. (2000). Screening of some Palestinian medicinal plants for antibacterial activity. Journal of Ethnopharmacology, 70(3), 343-349.

[7] Saxena, V. K., \& Sharma, R. N. (1999). Antimicrobial activity of the essential oil of Toddalia asiatica. Fitoterapia, 70(1), 64-66.

[8] Nimri, L. F., Meqdam, M. M., \& Alkofahi, A. (1999). Antibacterial activity of Jordanian medicinal plants. Pharmaceutical biology, 37(3), 196-201.

[10] Sarac, N., \& Ugur, A. (2007). Antimicrobial activities and usage in folkloric medicine of some Lamiaceae species growing in Mugla, Turkey. EurAsian Journal of BioSciences, 4, 28-37.

[11] Hammer, K. A., Carson, C. F., \& Riley, T. V. (1999). Antimicrobial activity of essential oils and other plant extracts. Journal of applied microbiology, 86(6), 985-990.

[12] Tipu, M. A., Akhtar, M. S., Anjum, M. I., \& Raja, M. L. (2006). New dimension of medicinal plants as animal feed. Pak Vet J, 26(26), 144-148.

[13] Mitscher, L. A., Drake, S., Gollapudi, S. R., \& Okwute, S. K. (1987). A modern look at folkloric use of anti-infective agents. Journal of natural products, 50(6), 1025-1040.

[14] Eloff, J. N. (1998). Which extractant should be used for the screening and isolation of antimicrobial components from plants?. Journal of ethnopharmacology, 60(1), 1-8.

[15] Bhaskarwar, B. H. U. S. H. A. N., Itankar, P., \& Fulke, A. (2008). Evaluation of antimicrobial activity of medicinal plant Jatropha podagrica (Hook). Roumanian Biotechnological Letters, 13(5), 3873-3877.

[16] Raja, R. R. (2012). Medicinally potential plants of Labiatae (Lamiaceae) family: an overview. Research journal of medicinal plant, 6(3), 203-213.

[17] Baser, K. H. C. (1992, July). Essential oils of Anatolian Labiatae: a profile. In WOCMAP I-Medicinal and Aromatic Plants Conference: part 1 of 4, 333, 217-238.

[18] Nemeth, E., \& Bernath, J. (2008). Biological activities of yarrow species (Achillea spp.). Current pharmaceutical design, 14(29), 3151-3167.

[19] Si, X. T., Zhang, M. L., Shi, Q. W., \& Kiyota, H. (2006). Chemical constituents of the plants in the genus Achillea. Chemistry \& biodiversity, 3(11), 1163-1180.

[20] Baytop, T. (1999). Therapy with medicinal plants in Turkey (Past and Present).

[21] Salem, M. Z., Ali, H. M., El-Shanhorey, N. A., \& Abdel-Megeed, A. (2013). Evaluation of extracts and essential oil from Callistemon viminalis leaves: Antibacterial and antioxidant activities, total phenolic and flavonoid contents. Asian Pacific journal of tropical medicine, 6(10), 785-791.

[22] Wayne, P. A. (2010). Clinical and Laboratory Standards Institute (CLSI); 2010. Performance standards for antimicrobial susceptibility testing, 20. 